\title{
Front Matter: Volume 10469
}

, "Front Matter: Volume 10469," Proc. SPIE 10469, Optical Imaging, Therapeutics, and Advanced Technology in Head and Neck Surgery and Otolaryngology 2018, 1046901 (2 May 2018); doi: 10.1117/12.2315646

SPIE. Event: SPIE BiOS, 2018, San Francisco, California, United States 


\title{
PROGRESS IN BIOMEDICAL OPTICS AND IMAGING

\section{Optical Imaging, Therapeutics, and Advanced Technology in Head and Neck Surgery and Otolaryngology 2018}

\author{
Brian J. F. Wong \\ Justus F. llgner \\ Max J. Witjes \\ Editors
}

27-28 January 2018

San Francisco, California, United States

Sponsored by

SPIE

Cosponsored by

Head and Neck Optical Diagnostics and Intervention Society

Published by

SPIE 
The papers in this volume were part of the technical conference cited on the cover and title page. Papers were selected and subject to review by the editors and conference program committee. Some conference presentations may not be available for publication. Additional papers and presentation recordings may be available online in the SPIE Digital Library at SPIEDigitalLibrary.org.

The papers reflect the work and thoughts of the authors and are published herein as submitted. The publisher is not responsible for the validity of the information or for any outcomes resulting from reliance thereon.

Please use the following format to cite material from these proceedings:

Author(s), "Title of Paper," in Optical Imaging, Therapeutics, and Advanced Technology in Head and Neck Surgery and Otolaryngology 2018, edited by Brian J. F. Wong, Justus F. Ilgner, Max J. Witjes, Proceedings of SPIE Vol. 10469 (SPIE, Bellingham, WA, 2018) Seven-digit Article CID Number.

ISSN: 1605-7422

ISSN: 1996-756X (electronic)

ISBN: 9781510614239

ISBN: 9781510614246 (electronic)

Published by

SPIE

P.O. Box 10, Bellingham, Washington $98227-0010$ USA

Telephone +1 3606763290 (Pacific Time) · Fax +1 3606471445

SPIE.org

Copyright (C) 2018, Society of Photo-Optical Instrumentation Engineers.

Copying of material in this book for internal or personal use, or for the internal or personal use of specific clients, beyond the fair use provisions granted by the U.S. Copyright Law is authorized by SPIE subject to payment of copying fees. The Transactional Reporting Service base fee for this volume is $\$ 18.00$ per article (or portion thereof), which should be paid directly to the Copyright Clearance Center (CCC), 222 Rosewood Drive, Danvers, MA 01923. Payment may also be made electronically through CCC Online at copyright.com. Other copying for republication, resale, advertising or promotion, or any form of systematic or multiple reproduction of any material in this book is prohibited except with permission in writing from the publisher. The CCC fee code is 1605$7422 / 18 / \$ 18.00$.

Printed in the United States of America.

Publication of record for individual papers is online in the SPIE Digital Library.

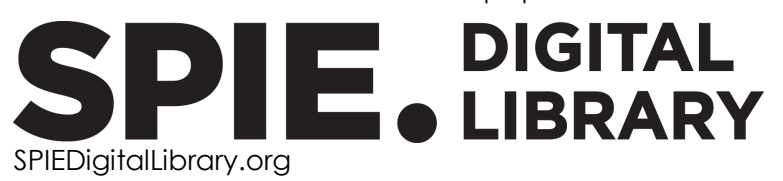

Paper Numbering: Proceedings of SPIE follow an e-First publication model. A unique citation identifier (CID) number is assigned to each article at the time of publication. Utilization of CIDs allows articles to be fully citable as soon as they are published online, and connects the same identifier to all online and print versions of the publication. SPIE uses a seven-digit CID article numbering system structured as follows:

- The first five digits correspond to the SPIE volume number.

- The last two digits indicate publication order within the volume using a Base 36 numbering system employing both numerals and letters. These two-number sets start with $00,01,02,03$, 04, 05, 06, 07, 08, 09, 0A, OB ... 0Z, followed by 10-1Z, 20-2Z, etc. The CID Number appears on each page of the manuscript. 


\title{
Contents
}

\author{
$\checkmark \quad$ Authors \\ vii Conference Committee \\ ix Introduction
}

HEARING AND DISEASES OF THE EAR

10469 OU Electrical and optical co-stimulation in the deaf white cat [10469-30]

NBI AND OPTICAL BIOPSY I

10469 0X Optical biopsy of head and neck cancer using hyperspectral imaging and convolutional neural networks [10469-33]

NBI AND OPTICAL BIOPSY II

1046912 Diffuse Reflectance Spectroscopy (DRS) of radiation-induced re-oxygenation in sensitive and resistant head and neck tumor xenografts [10469-38]

NOVEL THERAPEUTICS, PDT, AND ROBOTICS

10469 IE Antibacterial studies of ZnO nanoparticle coatings on nanocrystalline YSZ irradiated with femtosecond laser light [10469-52] 
Proc. of SPIE Vol. $104691046901-4$

Downloaded From: https://www.spiedigitallibrary.org/conference-proceedings-of-spie on 26 Apr 2023 Terms of Use: https://www.spiedigitallibrary.org/terms-of-use 


\title{
Authors
}

Numbers in the index correspond to the last two digits of the seven-digit citation identifier (CID) article numbering system used in Proceedings of SPIE. The first five digits reflect the volume number. Base 36 numbering is employed for the last two digits and indicates the order of articles within the volume. Numbers start with 00, 01, 02, 03, 04, 05, 06, 07, 08, 09, OA, OB...0Z, followed by 10-1Z, 20-2Z, etc.

\author{
Aguilar, Guillermo, 1E \\ Alvarez, Crysthal, 1E \\ Cao, Zhiping, OU \\ Chen, Amy Y., OX \\ Cuando, Natanael, $1 \mathrm{E}$ \\ Dadgar, Sina, 12 \\ El-Deiry, Mark W., OX \\ Fei, Baowei, OX \\ Garcia, Valeria, $1 \mathrm{E}$ \\ Griffith, Christopher C., OX \\ Halicek, Martin, OX \\ Little, James $\mathrm{V}_{\text {., OX }}$ \\ Patel, Mihir, OX \\ Rajaram, Narasimhan, 12 \\ Richter, Claus-Peter, OU \\ Robinson, Alan, OU \\ Rodríguez Troncoso, Joel, 12 \\ Suematsu, Naofumi, OU \\ Tan, Xiaodong, OU \\ Wang, $X \cup, O X$ \\ $\mathrm{XU}$, Yingyue, OU
}


Proc. of SPIE Vol. 10469 1046901-6

Downloaded From: https://www.spiedigitallibrary.org/conference-proceedings-of-spie on 26 Apr 2023 Terms of Use: https://www.spiedigitallibrary.org/terms-of-use 


\title{
Conference Committee
}

\author{
Symposium Chairs
}

James G. Fujimoto, Massachusetts Institute of Technology

(United States)

R. Rox Anderson, Wellman Center for Photomedicine, Massachusetts General Hospital (United States) and Harvard Medical School (United States)

Program Track Chair

Brian J. F. Wong, Beckman Laser Institute and Medical Clinic (United States)

Conference Chairs

Brian J. F. Wong, Beckman Laser Institute and Medical Clinic (United States)

Justus F. Ilgner, Uniklinik RWTH Aachen (Germany)

Max J. Witjes, University Medical Center Groningen (Netherlands)

Conference Program Committee

Christian Stephan Betz, Klinikum der Universität München (Germany)

Phil-Sang Chung, Dankook University Hospital (Korea, Republic of)

Waseem K. Jerjes, University College London (United Kingdom)

Joseph C. Jing, Beckman Laser Institute and Medical Clinic (United States)

Milind Rajadhyaksha, Memorial Sloan-Kettering Cancer Center (United States)

Henricus J. C. M. Sterenborg, Erasmus MC (Netherlands)

\section{Session Chairs}

1 Airway Imaging and Vocal Fold Dynamics I

Brian J. F. Wong, Beckman Laser Institute and Medical Clinic (United States)

2 Airway Imaging and Vocal Fold Dynamics II

Justus F. Ilgner, Uniklinik RWTH Aachen (Germany) 
3 Optically Guided Cancer Surgery I

Max J. Witjes, University Medical Center Groningen (Netherlands)

Joseph C. Jing, Beckman Laser Institute and Medical Clinic

(United States)

4 Optically Guided Cancer Surgery II

Phil-Sang Chung, Dankook University Hospital (Korea, Republic of)

$5 \quad$ Hearing and Diseases of the Ear

Justus F. Ilgner, Uniklinik RWTH Aachen (Germany)

Phil-Sang Chung, Dankook University Hospital (Korea, Republic of)

$6 \mathrm{NBI}$ and Optical Biopsy I

Henricus J. C. M. Sterenborg, Erasmus MC (Netherlands)

Milind Rajadhyaksha, Memorial Sloan-Kettering Cancer Center (United States)

$7 \mathrm{NBI}$ and Optical Biopsy II

Henricus J. C. M. Sterenborg, Erasmus MC (Netherlands)

Milind Rajadhyaksha, Memorial Sloan-Kettering Cancer Center (United States)

8 Novel Therapeutics, PDT, and Robotics

Max J. Witjes, University Medical Center Groningen (Netherlands) 


\section{Introduction}

The 10th Scientific Meeting of the Head and Neck Optical Diagnostics Society was held in conjunction with the annual SPIE Photonics West BiOS Conference in San Francisco, 27-28 January 2018. The scientific meeting, which was titled "Optical Imaging, Therapeutics, and Advanced Technology in Head and Neck Surgery and Otolaryngology 2018," covered a broad range of topics regarding non- to minimally invasive imaging modalities to assess airway and vocal fold dynamics, optically guided cancer surgery, and auditory diseases; and the development of new technologies and therapeutics. Presentations covered imaging techniques such as: optical coherence tomography (OCT), narrow band imaging (NBI), diffuse reflectance spectroscopy (DRS), fluorescence lifetime imaging (FLIM), and Raman spectroscopy; and their applications in Otolaryngology-Head and Neck Surgery.

The first two sessions titled "Airway Imaging and Vocal Fold Dynamics" discussed optical coherence tomography for phono-microsurgery, machine learning algorithms for high speed laryngeal imaging and near-infrared spectroscopy, and the comparison of various newly developed OCT systems for laryngeal imaging. As the vocal cords are a sensitive functional structure, it is pertinent to explore means of screening technologies as an adjunct to biopsy to guide surgical intervention to only remove diseased tissue. Similarly, machine learning algorithms coupled with high speed laryngeal imaging were presented as an adjunct to vocal fold assessment. With the emerging new trends accessibility in large data, machine learning algorithms and their respective structures have gained immense interest.

The sessions titled "Optically Guided Cancer Surgery" discussed the use of various imaging modalities to intraoperatively screen and delineate tumor margins of oral neoplasia and squamous cell carcinoma. These optical imaging modalities including FLIM, widefield imaging using fluorescently labeled antibodies, confocal imaging, hyperspectral imaging, and diffuse reflectance spectroscopy, incorporate radiology, pathology, and surgery for real time or almost real time analysis. Research in this area has rapidly advanced and many of these technologies have been studied intraoperatively. However, many challenges were also discussed, such as accurate correlation to pathology and the need to focus imaging goals on the deep margins that lead to the most disease recurrence.

In the next session, titled "Hearing and Diseases of the Ear," minimally invasive optical approaches to screen and diagnose changes in auditory anatomy and functionality, including the tympanic membrane and cochlea, were explored. Spectroscopic and intensity based structural techniques to differentially diagnose otitis media were presented. The combination of electrical and infrared neural stimulation to reduce the threshold required for cochlea implants and reduce 
thermal damage was discussed to close the session. Despite the challenges of the invasiveness of optical imaging in the ear, these technologies allow for development of more precise individualized medical therapies and accurate assessment of therapeutic efficacy.

The sessions titled "NBI and Optical Biopsy" included presentations that discussed the use of $\mathrm{NBI}$ and other various imaging modalities to non-invasively or minimallyinvasively differentiate pathologies in the head and neck. Hyperspectral imaging in conjunction with neural networks were discussed as a means of optical biopsy for head and neck cancers. Narrow band imaging and autofluorescence lifetime endoscopy were presented as imaging modalities used to reduce local recurrence and detect early stage oral cancer and dysplasia respectively. Lastly, near-infrared autofluorescence was shown to guide parathyroid gland mapping in thyroidectomies and related procedures.

The final session, "Novel Therapeutics, Photodynamic Therapy, and Robotics," concluded the scientific meeting. It is well understood that surgeons have a limited capability in accessing the complicated anatomical structures in the head and neck. Due to the ability of robotics to access these areas, the use of robotic surgery has greatly increased in the recent years. With the emerging combination of optics in robotic surgery, head and neck surgeons are now able to assess tissue micro-pathology non-invasively when tactile feedback is not provided by the robot. Particularly, fluorescence lifetime imaging was discussed as a powerful optical tool for transoral robotic surgery. The development and improvement of new therapies and surgical tools were also discussed. New devices, such as a cranial implant comprised of nanocrystalline yttria-stabilized zirconia to optically access the brain, were presented with modifications for appropriate clinical use. In addition, advancements in interstitial photodynamic therapy (PDT) treatment and PDT with Cetuximan-IR700DX was explored.

Various tomographic and spectroscopic non- to minimally invasive imaging modalities were presented to assess changes in healthy and abnormal otolaryngology-head and neck tissues. It is evident that the focus of imaging work is on highly sensitive organs which should be adequately preserved, which includes but is not limited to the vocal folds, oral cavity, and cochlea. The future of imaging technologies in otolaryngology can provide avenues for drug discovery and further understanding of disease pathology. System developments and improvements in analytical models of these imaging technologies inch them closer to clinical application. Improving the quantifiable measures towards tissue classification provides detailed information that is otherwise limited by traditional methods. The papers collected in this special proceedings issue can be expected to deepen our understanding of the uses of such technologies and their future implications.

The conference was led by chairs Brian J. F. Wong M.D. Ph.D. (Beckman Laser Institute and Medical Clinic, United States), Justus F. llgner Prof. Dr. med. (Uniklinik RWTH Aachen, Germany), and Max J. Witjes M.D. D.D.S. Ph.D. (University Medical 
Center Groningen, Netherlands). The program committee included Christian Stephan Betz Prof. Dr. med. (Klinikum der Univ. Munchen, Germany), Phil-Sang Chung M.D. (Dankook Univ. Hospital, Korea, Republic of), Waseem K. Jerjes M.D.res. PhD. (Univ. Collegen London, United Kingdom), Joseph C. Jing Ph.D. (California Institute of Technology, United States), Milind Rajadhyaksha Ph.D. (Memorial Sloan-Kettering Cancer Center, United States), and Henricus J. C. M. Sterenborg Ph.D. (Erasmus MC, Netherlands).

Brian J. F. Wong

Justus F. llgner

Max J. Witjes

Tiffany T. Pham 
Proc. of SPIE Vol. 10469 1046901-12 Downloaded From: https://www.spiedigitallibrary.org/conference-proceedings-of-spie on 26 Apr 2023
Terms of Use: https://www.spiedigitallibrary.org/terms-of-use 